\title{
Aprosdokitos mikrotero gen. et sp. nov., the tiniest Sphenisciformes that lived in Antarctica during the Paleogene
}

\author{
Carolina Acosta Hospitaleche, Marcelo Reguero, and Sergio Santillana
}

With 5 figures and 1 table

\begin{abstract}
A small humerus from Eocene levels of Seymour Island, Antarctica is assigned here to Aprosdokitos mikrotero sp. and gen. nov. (Aves, Sphenisciformes), based predominantly on its small size. An ontogenetic series based on Pygoscelis antartica was established for comparative purposes, and evaluation of pathological conditions was also carried out in order to rule out other possible sources of size variation.
\end{abstract}

Key words: Spheniscidae, Seymour Island, Eocene, humerus.

\section{Introduction}

Penguins were and are a successful group of seabirds that have conquered different ecological niches, occupying marine coasts in diverse cold and temperate environments around the world. As a group, they are viewed as conservative because their morphology shows little change since the Paleocene, although body size appears to be a variable feature both temporally and geographically.

Antarctic penguins are mainly represented by large and giant species, although in fact, the high diversity found during the Eocene in Seymour Island includes a wide spectrum of sizes. Small-sized penguins are represented in Antarctica by Delphinornis, Mesetaornis and Marambiornis, diagnosed from tarsometatarsi without associated humeri (MYrCHA et al. 2002).

Other tiny species are recorded also outside Antarctica, such as Eretiscus tonni from the early Miocene of Argentina, and the Hakataramea penguin (FORDYCE \& JONES 1990), subsequently nominated by ANDo (2007) as "Pakudyptes hakataramea" in his unpublished dissertation, from the latest Oligocene-earliest Miocene of New Zealand, besides the living Eudyptula minor, found in New Zealand, Australia, Chatham Is., and Tasmania (MARTínez 1992). However, size is the only similarity shared among these species (see description below for details).

Although most penguin species have been diagnosed based on their tarsometatarsi, the systematic importance of the humerus has been repeatedly highlighted. An extensive list of humeral characters has been proposed to analyze the relationships between Paleogene taxa, although it has not been possible yet to score them in the smallest Antarctic species due to the absence of comparable elements (see CHAVEZHOFFMEISTER 2014).

The present contribution is motivated by the finding of two very small Antarctic humeri belonging to penguins in the Eocene La Meseta Formation and Submeseta Formation, Seymour (Marambio) Island, Antarctic Peninsula (Fig. 1). Because of the strikingly small size of these bones, three issues are addressed here: 1. Ontogenetic stage, 2. Comparative morphology, including possible anomalies, and 3. Systematic assignment. 


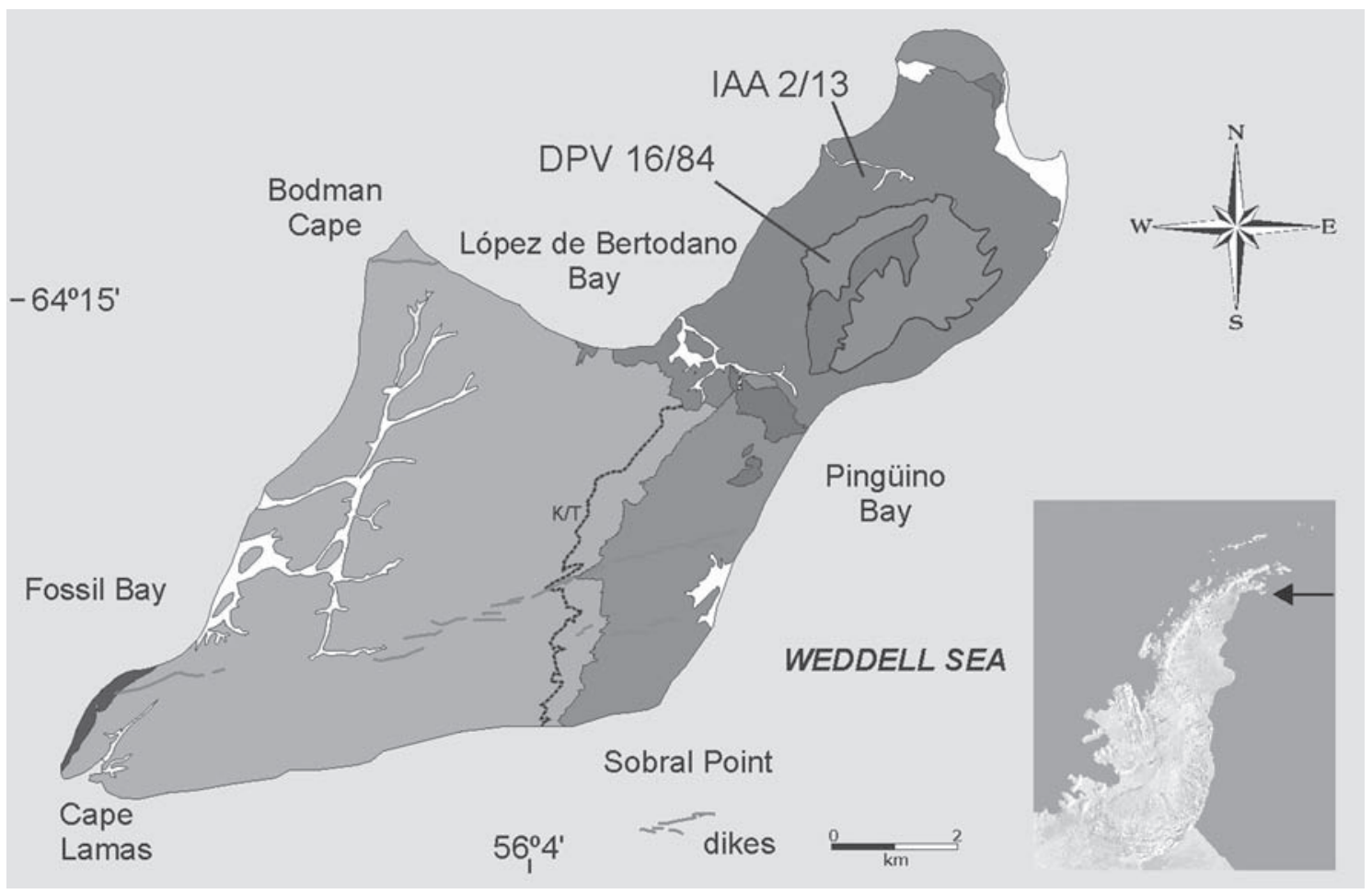

Fig. 1. Map of Seymour Island (Antarctic Peninsula, West Antarctica), pointing the fossil localities DPV 16/84 and IAA $2 / 13$ where the humeri described here were found. At the right, the arrow is showing the location of Seymour Island, near the tip of the Peninsula.

\section{Material and methods}

Humeri were collected during summer campaigns of Instituto Antártico Argentino (Dirección Nacional del Antártico) and are housed in the División Paleontología de Vertebrados of Museo de La Plata (MLP), Argentina.

A complete ontogenetic series based on skeletons of the modern Antarctic penguin Pygoscelis antarctica, including chicks, juveniles, sub-adults and adult specimens was established for comparative purposes (see Table 1). For the fossil specimens, as well as for each skeleton of the series, degree of ossification, development of structures and textural aging was compared following TUMARKIN-DERATZIAN et al. (2006).

Once the ontogenetic stage of fossils had been determined, the possibility of abnormal development of the wing was considered. Different pathologies were considered by comparison with descriptions published in the literature (RAIDAL et al. 2006).

Comparative material includes 400 humeri from the Eocene of Antarctica, which are currently under study, belonging to the Argentinean collection at the Museo de La Plata and those described in JADWISZCZAK (2006) and TAMBUSS et al. 2006. Terminology follows the proposals of BAUMEL \& WitMer (1993) and Livezey \& Zusi (2006). Measurements were taken using a Vernier caliper $(0.01 \mathrm{~mm}$ increments).
Table 1. Ontogenetic series based on Pygoscelis antartica established for comparative purposes.

\begin{tabular}{c|c}
\hline Repository number & Age \\
\hline 1769 & newborn \\
\hline 790 & 7 days old \\
\hline 805 & 10 days old \\
\hline 788 & 2 weeks old \\
\hline 786 & 2 weeks old \\
\hline 789 & 3 weeks old \\
\hline 787 & 4 weeks old \\
\hline 817 & 5 weeks old \\
\hline 809 & 6 weeks old \\
\hline 812 & 8 weeks old \\
\hline 807 & 10 months old \\
\hline 806 & 1 year old \\
\hline
\end{tabular}

\section{Geographic and stratigraphic provenance}

The Seymour Island Group includes the middle-late Paleocene Cross Valley Formation, the latest Paleocene- middle Eocene La Meseta Formation, and the middle Eocene-?Oligocene Submeseta Formation. The 


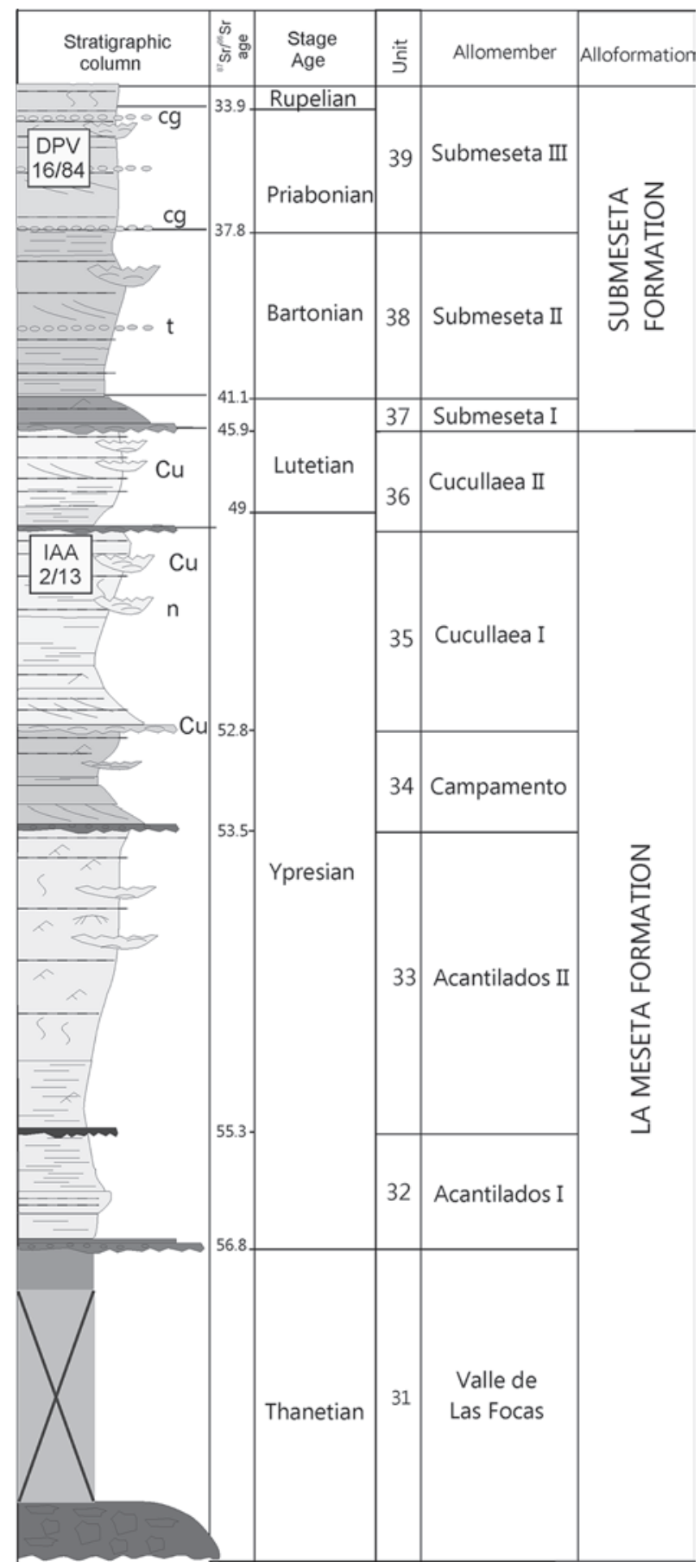

Fig. 2. Stratigraphic column showing the fossil localities in the sequence. References: cg, conglomerates, t, Turritella bank, $\mathrm{Cu}$, Cucullaea coquina, n, Naticid bank.

La Meseta and Submeseta formations are the main Cenozoic strata of the James Ross Basin, exposed around the northern part of Seymour Island (DEL VALLE et al. 1992) (Fig. 1).
The La Meseta Alloformation (Fig. 2), sensu MARENSSI et al. 1998a (= La Meseta Formation) includes mudstones and sandstones with interbedded conglomerates. It is internally organized in six lensshaped units that represent different sedimentation stages related to sea level fluctuations (MARENSSI et al. 2002). These erosionally-based allomembers, named Valle de Las Focas, Acantilado I, Acantilado II, Campamento, Cucullaea I, and Cucullaea II (MonTes et al. 2013), were deposited in deltaic, estuarine and shallow marine environments (PoRĘBSKI 1995; MARENSSI et al. 1998b). The humerus MLP 13-IX-28-385 was collected at the fossil locality IAA 2/13 (also informally known as "Simil RV") which encompasses outcropping levels of Cucullaea I Allomember (Ypresian). These beds are correlated with DPV 6/84 (= RV 8200 for WoODBURNE \& ZinSMEISTER, 1984), belonging to levels deposited above to the Naticid gastropods levels.

The middle Eocene-earliest Oligocene Submeseta Formation (MonTEs et al. 2013) is divided into three levels (Fig. 2), named, from base to top, "Submeseta I", "Submeseta II", and "Submeseta III" (MonTes et al. 2013), and represents the uppermost part of the marine sedimentary sequence of the Basin (MARENSSI et al. 1998a). The humerus MLP 00-I-1-19 comes from the Submeseta III levels (Priabonian); it was collected at the locality DPV 16/84, with the latest deposits of the cycle.

These levels correspond to the Facies Association III, characterized by a uniform sandy lithology that represents a tidal shelf influenced by storms (MARENSSI et al. 1998b).

\section{Ontogenetic determination}

Due to the extreme small size of the remains, their ontogenetic stage was thoroughly analyzed. Both materials were compared with humeri of an ontogenetic series comprising twelve age categories based on specimens of Pygoscelis antarctica (Fig. 3), from a sample spanning from newborn chicks to one-year-old juveniles.

The comparative analysis of materials shows that the humerus does not acquire recognizable morphology in chicks younger than 15 days (Fig. 3A-D); the degree of flattening of the diaphysis being variable and increasing constantly with age. Adult morphology of the humeral diaphysis is achieved in chicks that are at least 20 days old (Fig. 3E-F). Ossification of the proximal epiphysis starts in 30-day-old birds (Fig. 3G); in addition, the humeral head becomes cranio-caudally broader and continues expanding until the juvenile 


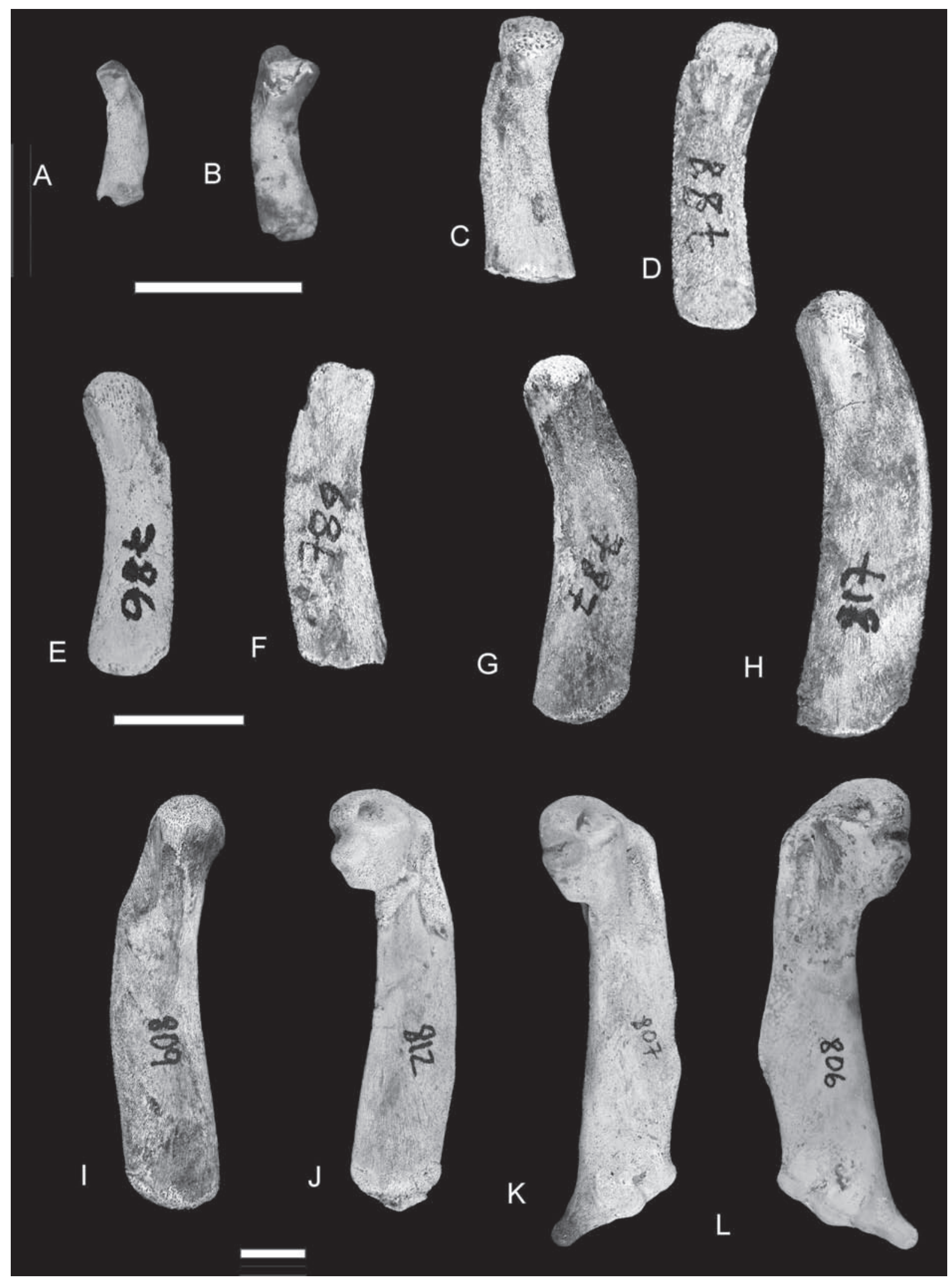

Fig. 3. Ontogenetic series constituted by Pygoscelis antarctica. A, MLP 1769 (newborn), B, MLP 790 (7 days old), C, MLP 805 (10 days old), D, MLP 788 (2 weeks old), E, MLP 786 (2 weeks old), F, MLP 787 (4 weeks old), G, MLP 817 (5 weeks old), H, MLP 809 (6 weeks old), I, MLP 812 (8 weeks old), J, MLP 807 (ten months old), K, MLP 806 (1 year old). Each line of photographs has its own scale. Scale bar $=10 \mathrm{~mm}$. 
stage (Fig. 3L). The impressions of the pectoral and supracoracoideus muscles become clearly differentiated between the third and fourth month (Fig. 3J-K). These muscles are closely related with wing movements during diving. The appearance of their scars in the fourth month of life (Fig. 3J) is consistent with the age at which penguins begin their incursions into the ocean. In juveniles that are only barely smaller than adults, the head of the humerus is almost completely developed, and the tricipital fossa is formed, whereas the distal epiphysis is still not ossified (Fig. 3L). Ossification of the distal end is completed in one-year-old individuals, when the bird reaches adult size, and only textural aging allows clear distinction between these two age categories (Fig. 3L).

The fossils present complete ossification of the epiphyses (Fig. 4), which only occurs in adult and subadult penguins that have already reached adult size. This ossification is particularly evident in the distal end of the humerus MLP 00-I-1-19 (Fig. 4A-D) and allows its confident assignment to an adult penguin, and in the proximal end of MLP 13-IX-28-385 (Fig. 4E-G), which shows a completely developed caput humerus. In chicks and young juveniles, the distal epiphysis is rounded, neither the condyla nor the sulci $\mathrm{m}$. humerotricipitalis and scapulotricipitalis are recognizable (Fig. 3), and the head is not developed. In the fossils under study, all these structures and the processus flexorius (in MLP 00-I-1-19) are well developed (Fig. 4).

Textural aging is another feature that can easily indicate juvenile and sub-adult states of specimens because of incomplete ossification of the periosteal bone (Tumarkin-Deratzian et al. 2006, see also Watanabe 2016.). Thus, non-adult specimens are more susceptible to breakage and weathering. The surface of specimen MLP 00-I-1-19 is somewhat eroded, which could be mistakenly identified as the textural aging of a subadult bird, but in fact reflects only weathering. The surface of specimen MLP 13-IX-28-385 doubtlessly corresponds to an adult penguin.

\section{Concerning possible anomalous condi- tions of the humeri}

Congenital musculoskeletal disorders and deformities are rare in wild populations of birds, or possibly rarely recorded due to the individuals not surviving and anomalous characters not being passed on to new generations. In addition, such abnormalities are rare in the fossil record, and indeed no cases of penguins with this type of deformity have ever been reported.
However, some interesting pathologies have been described in birds, occurring in isolated individuals (see Schmidt et al. 2003). Most studies refer to poultry and only in a few cases involve penguins (PourLIS 2011). Particularly regarding pathologies affecting the flipper, two cases of micromelia have been reported for the living species Eudyptula minor (RAIDAL et al. 2006). These cases represent rare events, resulting from random non-heritable genetic defects that occur during limb development, or possibly caused by exposure to teratogenic toxins. In both specimens, the affection was unilateral and the wing was significantly shortened. In cases of micromelia such as these, the humerus is also abnormally developed, and this condition can be easily detected. None of these cases consisted simply of reduction of bone size; they also involved noticeable distortions in shape. This is not the case of the fossils studied here, whose only abnormality is their size. In summary, the specimens MLP 00-I-1-19 and MLP 13IX-28-385 are completely ordinary in terms of their morphology and there is no reason to consider that they represent an abnormal condition.

\section{Systematic paleontology}

\section{Order Sphenisciformes \\ Genus Aprosdokitos nov.}

Type species: Aprosdokitos mikrotero sp. nov., monotypic.

Etymology: From Ancient Greek "aprosdóki_tos" meaning "unexpected", in reference to the unexpected finding of a new genus in the Eocene of Antarctica.

Diagnosis: As for type species.

Aprosdokitos mikrotero sp. nov. Figs. 4A-D, 5A

Material: MLP 00-I-1-19 (right humerus).

Etymology: Specific epithet mikrotero from the Greek word "mikrótero", meaning "the smallest", in reference to the very small size of the assigned humerus, the most striking feature of the specimen.

Type locality and age: DPV 16/84 Fossil site, Seymour Island (Antarctic Peninsula). Submeseta III, Submeseta Formation (Priabonian-Rupelian?). 


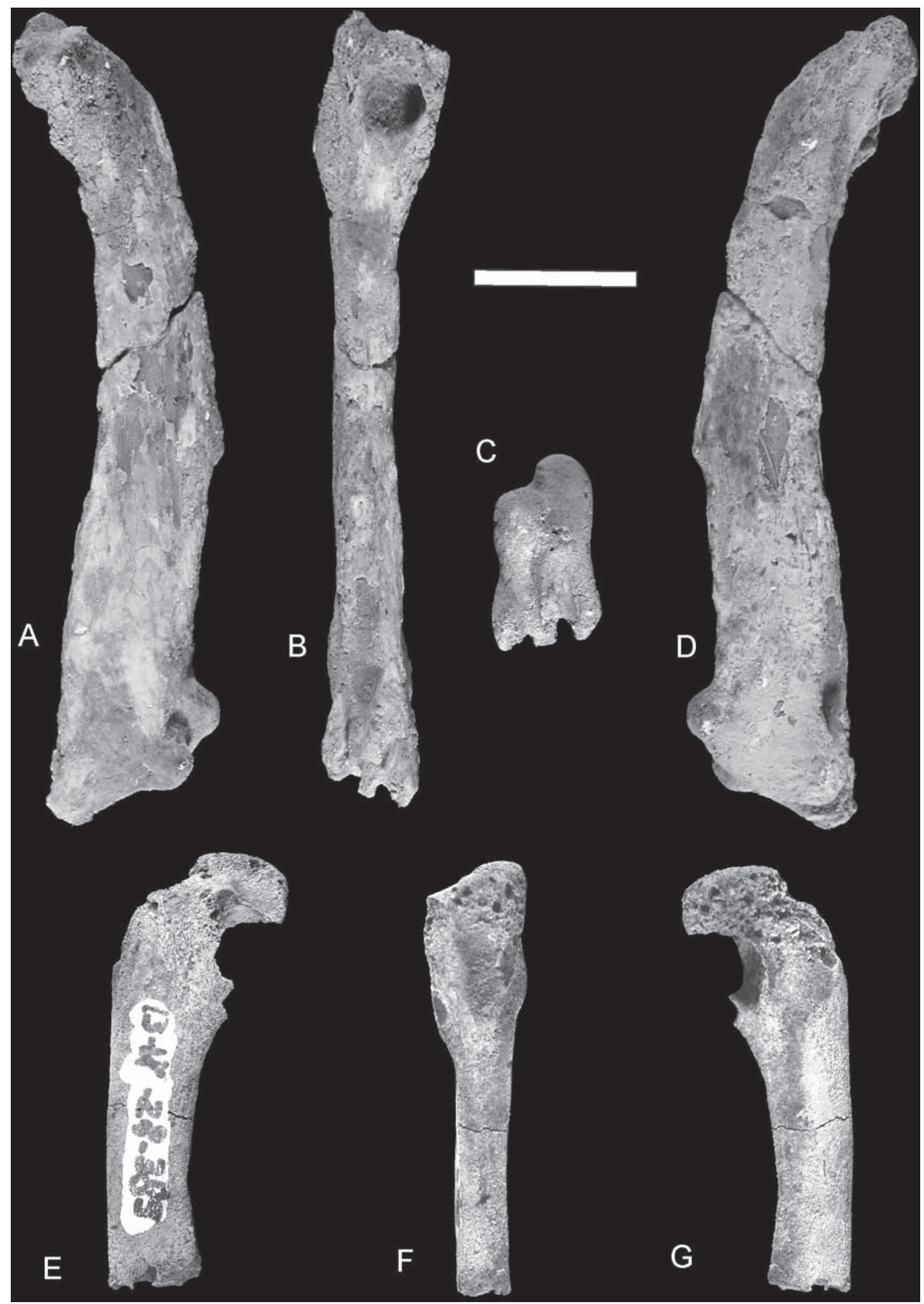

Fig. 4. A-D - Aprosdokitos mikrotero, MLP 00-I-1-19 (holotype, left humerus) A, cranial, B, medial, C, distal, and D, caudal views. E-G - Spheniscidae indet., MLP 13-IX-28-385 (right humerus) E, cranial, F, medial, and G, caudal views. Ammonium chloride powder was sublimated for fossil whitening. Scale bar $=10 \mathrm{~mm}$. 
Measurements: Total length: $50.8 \mathrm{~mm}$, distal width $9.5 \mathrm{~mm}$, width of diaphysis (taken proximally to the angulus preaxialis): $6.8 \mathrm{~mm}$, width of diaphysis (taken distally to the angulus preaxialis): $8.2 \mathrm{~mm}$, antero-posterior width of diaphysis: $3.9 \mathrm{~mm}$, antero-posterior width of distal epiphysis: $6.2 \mathrm{~mm}$.

Diagnosis: Very small humerus (ca. $50.8 \mathrm{~mm}$ ), with diaphysis broader distally to the angulus preaxialis and single fossa tricipitalis. Condylus dorsalis humeralis larger than the ventralis, which is located over the dorsal edge. Processus flexorius narrow and ventro-distally extended, cranial end of sulcus m. scapulotricipitalis curved caudally, and completely separated from the sulcus $m$. humerotricipitalis by an intermediate trochlear ridge.

Description: The humerus is small and slender. The diaphysis is almost completely straight (barely sigmoid), and the angulus preaxialis is well marked, dividing the shaft into a broader distal part and a narrower proximal part.

The proximal epiphysis is badly preserved, but some features are observable. The fossa tricipitalis is typically single and oval, with its main axis oriented proximo-distally. The caput humeris and the incisura capitis are broken, the crista bicipitalis is weakly developed. Only the distal fragment of the crista deltopectoralis is preserved, unfortunately without any portion of the impressio $m$. pectoralis.

The angle between the main axis and the tangent of the condylae is small, ca. $17^{\circ}$. The condylus dorsalis humeralis is larger than the condylus ventralis, which is located over the dorsal edge. Both condylae are spheroidal and conspicuous.

The processus flexorius is narrow and extended ventrodistally, ending in a rounded tip that is directed distally. The cranial end of the sulcus m. scapulotricipitalis is curved caudally, and completely separated from the sulcus m. humerotricipitalis by an intermediate trochlear ridge. The sulcus $m$. humerotricipitalis is deeper than the sulcus m. scapulotricipitalis. The fossa $\mathrm{m}$. brachialis is shallow.

In caudal view, a distal concavity separates the proximocaudal margin of the middle and ventral trochlear ridge from the edge of the shaft. The dorsal trochlear ridge barely surpasses the ventral margin of the shaft.

\section{Spheniscidae indet. Fig. 4E-G}

Material: MLP 13-IX-28-385 (half of the shaft and part of the proximal epiphysis of left humerus).

Provenance: IAA 2/13 Fossil site, Seymour Island (Antarctic Peninsula). Cucullaea I, La Meseta Formation (Ypresian).

Measurements: Width of diaphysis (taken proximally to the angulus preaxialis): $5.1 \mathrm{~mm}$, antero-posterior width of diaphysis: $3.2 \mathrm{~mm}$.

Description: This humerus is slightly smaller than MLP 00-I-1-19 and the shaft is slender and barely sigmoid. Like in Aprosdokitos mikrotero, the proximal epiphysis is globose and the fossa tricipitalis is single.
The crista deltopectoralis is ridge-like and the impressio $m$. deltopectoralis is shallow. At the broken part, the section of the bone shows marked pachyostosis. Its general morphology resembles MLP 00-I-1-19.

Systematic remarks: Assignment of MLP 00-I-1-19 and MLP13-IX-28-385 to the living Eudyptula minor, or to the fossil species Eretiscus tonni or the Hakataramea penguin ("Pakudyptes hakataramea" in ANDO 2007) can be easily rejected. The fossa tricipitalis is bipartite in those species as it is in all the Neogene and modern taxa (Acosta HospitalECHE et al. 2006: fig. 1; Haidr \& Acosta Hospitaleche 2015), whereas it is single in the materials studied here (Fig. 4).

The general morphology of the humeri described here is shared with other Paleogene penguins. For instance, in all these taxa the fossa tricipitalis is deep, single, and lacks a pneumatic foramen. A distal concavity separates the proximocaudal margin of the middle and ventral ridge from the margin of the shaft, as noted by CHÁvEZ- HoFFMEISTER (2014) in most basal penguins.

Considering the known Paleogene species, the correspondence of these specimens to any of the medium-sized, large or giant species can be ruled out. The huge difference in size precludes the assignment of MLP 00-I-1-19 and MLP 13-IX-28-385 to any species of Tonniornis, Archaeospheniscus, Palaeeudyptes, or Anthropornis. Therefore, only detailed comparisons to the smallest Antarctic fossil penguin species, i.e. Marambiornis, Mesetaornis, and Delphinornis (see table of humeri measurements for Antarctic species in JADWISZCZAK 2006) are worth considering.

Even though these three species were described from their tarsometatarsi, several humeri were later assigned to them (see JADWISZCZAK 2006 and TAMBUSSI et al. 2006). Although it has some degree of uncertainty, this systematic determination seems reasonable based on size and robustness. Moreover, in other cases, such tentative assignments based mainly on proportions and measurements were later confirmed through findings of more complete and articulated specimens (e.g., Palaeeudyptes gunnari and P. klekowskii in Acosta Hospitaleche \& Reguero 2010, 2014).

The humeri assigned to Marambiornis, Mesetaornis and Delphinornis are considerably larger (Fig. 5) than those of MLP 00-I-1-19 and MLP 13-IX-28-385. The former taxa were described from tarsometatarsi that are approximately $45 \mathrm{~mm}$ long (MүrсHA et al. 2002: table 1), and their humeri were estimated to be more than $90 \mathrm{~mm}$ long (see JADWISZCZAK 2006: table 14; TAMBUSSI et al. 2006). This is almost twice the length of the materials here described, which does not allow assignation of these humeri to any of these previously described species.

Fifteen humeri from the Polish collection have been indistinctly assigned to these three species (see JADWISZCZAK 2006: table 14). Considering the observed variation, those small humeri were divided into two major groups, one of them with two sub-groups, although none of them could be directly related to those species (JADWISZCZAK 2006). The groove between the margo caudalis and the hollow limited by the articular surface of the caput humeri, facies m. supracoracoidei and $f$. $m$. coracobrachialis caudalis mentioned by JADWISZCZAK (2006) as one of the diagnostic characters and illustrated for specimen IB/P/B-0132, is also observed in 


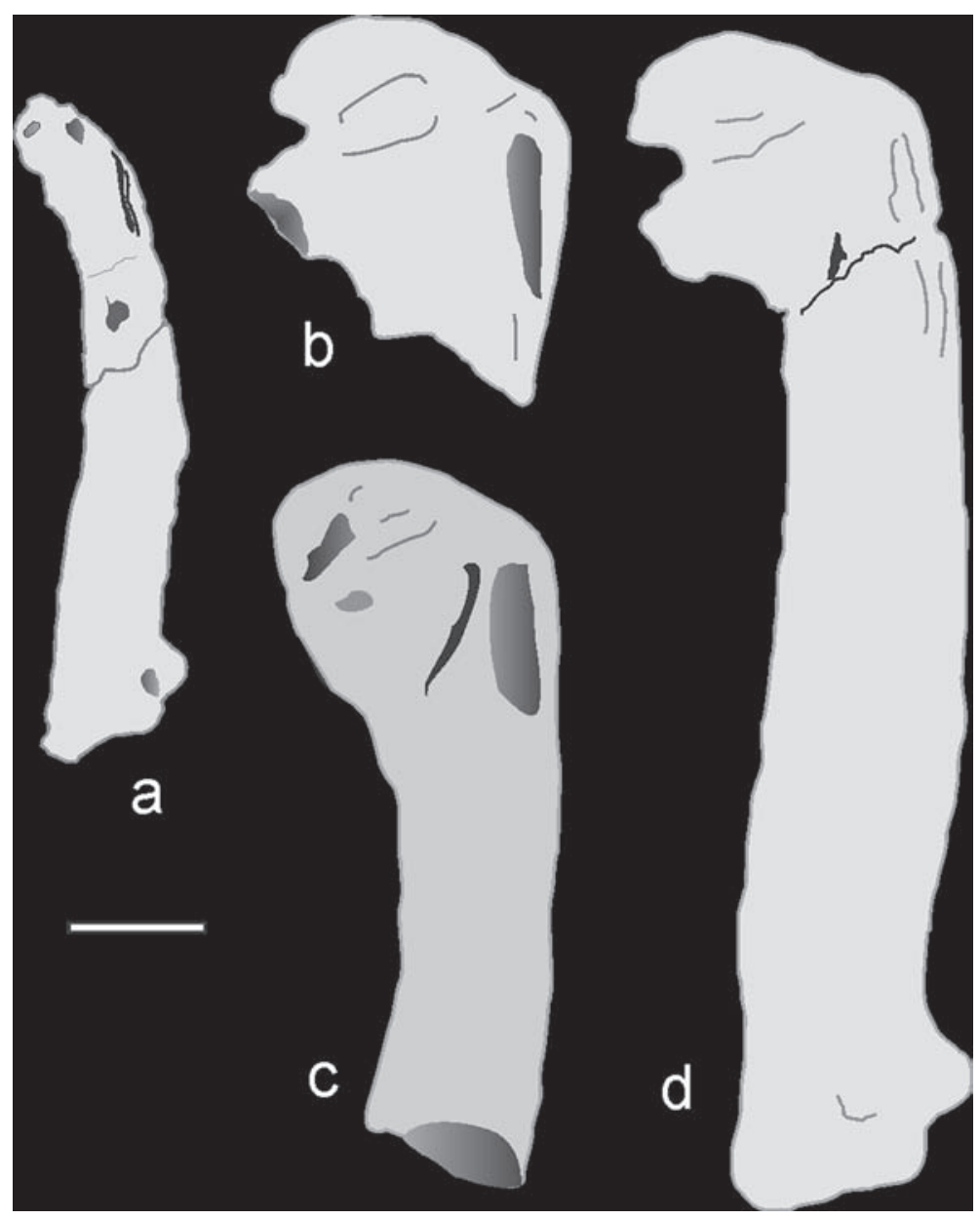

Fig. 5. Comparative scheme of: A, Aprosdokitos mikrotero MLP 00-I-1-19 and materials assigned genera of small-sized penguins: Delphinornis sp. and/or Mesetaornis polaris and/or Marambiornis exilis by JADWISZCZAK (2006: fig. 19, table 4): B, IB/P/B-0398 (mirrored image), C, IB/P/B-0132, D, IB/P/B-0382 (mirrored image). Images B, C, and D were taken from JADWISZCZAK (2006) and re-drawn with his permission. Scale bar $=10 \mathrm{~mm}$.

MLP 00-I-1-19 (MLP 13-IX-28-385 is broken in this region). The major differences with respect to previously described materials seem to be related to size and robustness. Both materials described here are extremely small and slender, with weak, compressed and barely sigmoid shafts.

\section{Discussion and conclusions}

The preparation of an ontogenetic series from extant penguins was extremely important not only for comparison of the elements assigned here to Aprosdokitos, but also for the study of other remains. The most distinctive feature of Aprosdokitos mikrotero is its small size, which is about half of that of other known fossil Eocene penguins of Antarctica; thus, establishing whether the individuals were adult was a crucial step in this study.

Abnormalities and known pathologies affecting the wing were also discarded, particularly those that could result in shortening of the long bones. Both materials correspond to normal adult penguins.

Previously known Antarctic humeri were grouped into fourteen species by TAMBUSSI et al. (2006) and alternatively, into ten species by JADWISZCZAK (2006). In any case, regardless of the number of species recognized, the result of this study is the same. After direct comparison with more than 400 specimens, MLP 00I-1-19 and MLP 13-IX-28-385 cannot be assigned to any known species. 
Both new fossils have a single fossa tricipitalis, whereas in all living species as well as in the small Neogene penguin Eretiscus tonni and the Hakataramea penguin, this fossa is bipartite. The tiny size precludes assignment to any of the giant, large and medium-sized species, and thus only Marambiornis, Mesetaornis and Delphinornis were considered for further comparisons. Based on tarsometatarsal measurements, these three taxa, as well as the unnominated materials mentioned by JADWISZCZAK (2006), would be larger than MLP 00-I-1-19 and MLP 13-IX-28-385. These new humeri are extremely slender, and their diaphyses are slightly curved and only weakly sigmoid.

Even though both humeri were found isolated, and most penguin taxa are currently diagnosed from partial skeletons, or at least by the presence of a tarsometatarsus, the specimens MLP 00-I-1-19 and MLP 13-IX-28385 can be differentiated from every known fossil and living penguin species, reason enough to consider them as a new taxon. The MLP 00-I-1-19 is assigned here to Aprosdokitos mikrotero, the smallest Antarctic species ever described. The MLP 13-IX-28-385 shares its size and others similarities with $A$. mikrotero, although we prefer to keep it as an indeterminate species due its fragmentary condition.

\section{Acknowledgements}

We thank the Instituto Antártico Argentino-Dirección Nacional del Antártico (IAA-DNA) and PICTO 2010- 0093 for inviting us to the field trip, Fuerza Aérea Argentina for the logistic support, and the rest of the Heidi Group which participated in the field work. We also thank Dr. DiEgo MonTAlti (Museo de La Plata, La Plata, Argentina) for access to material used to establish an ontogenetic series, and the reviewers Dr. Julian Hume and Dr. Washington Jones, who kindly commented on the first version of this manuscript. PIP 20120017 and PICT 20110284 partially supported this research. BRUNO PIANZOLA took the photographs and CECILIA MoRGan improved the English.

\section{References}

Acosta Hospitaleche, C., Degrange, F., Tambussi, C., CorRADO, N. \& Rustán, J.J. (2006): Evaluación de los caracteres del húmero de los pingüinos actuales y fósiles para su uso con fines sistemáticos. - Ornitología Neotropical, 17 (1): 81-94.

Acosta Hospitaleche, C. \& Reguero, M. (2010): First articulated skeleton of Palaeeudyptes gunnari from the late Eocene of Seymour (= Marambio) Island (Antarctica). - Antarctic Sciences, 22: 289-298.

Acosta Hospitaleche, C. \& Reguero, M. (2014): Palaeeudyptes klekowskii, the most complete penguin skeleton found in the Eocene of Antarctica: taxonomic remarks. - Geobios, 47: 77-85.

Ando, T. (2007): New Zealand fossil penguins: origin, pattern, and process. - PhD thesis, University of Otago, 364 pp.

Baumel, J.J. \& Witmer, L.M. (1993): Osteologia. - In: Baumel, J.J., King, A.S, Breazile, J.E., Evans, H.E. \& VAnden Berge, J.C. (Eds.): Handbook of Avian Anatomy: Nomina Anatomica Avium. - Publications of the Nuttall Ornithological Club, 23. 45-132.

Chávez-Hoffmeister, M. (2014): Phylogenetic characters in the humerus and tarsometatarsus of penguins. - Polish Polar Research, 35 (3): 469-496.

Del Valle, R.A., Elliot, D.H. \& Macdonald, D.I.M. (1992): Sedimentary basins on the east flank of the Antarctic Peninsula: proposed nomenclature. - Antarctic Science, 4: 477-478.

Fordyce, R.E. \& Jones, C.M. (1990): Penguin history and new fossil material from New Zealand. - In: DAvIS L.S. \& Darby, J.T. (Eds.): Penguin Biology: 419-446; San Diego (Academic Press).

Haidr, N., Acosta Hospitaleche, C. \& Quintana, F. (2015): Análisis morfo-funcional comparativo del húmero de pingüinos piscívoros y crustacívoros. - XVI Reunión Argentina de Ornitología. Actas, 32. La Plata, 9 al 12 de septiembre de 2015.

JADWISZCZAK, P. (2006): Eocene penguins of Seymour Island, Antarctica: Taxonomy. - Polish Polar Research, 27: 3-62.

Livezey, B.C. \& Zusi, R.L. (2006): Higher-order phylogeny of modern birds (Theropoda, Aves: Neornithes) based on comparative anatomy. I. Methods and characters. Bulletin of the Carnegie Museum of Natural History, 37: 1-544.

Marensi, S.A., Santillana, S.N. \& Rinaldi, C.A. (1998a): Paleoambientes sedimentarios de la Aloformación La Meseta (Eoceno), Isla Marambio (Seymour), Antártida. Instituto Antártico Argentino, Contribución, 464: 51 pp.

Marenssi, S.A., Santillana, S.N. \& Rinaldi, C.A. (1998b): Stratigraphy of the La Meseta Formation (Eocene), Marambio (Seymour) Island, Antarctica. - In: CASAdío, S. (Ed.), Paleógeno de América del Sur y de la Península Antártica. - Asociación Paleontológica Argentina, Publicación Especial, 5: 137-146.

Marenssi, S.A, Net, L.I. \& Santillana, S.N. (2002): Provenance, depositional and paleogeographic controls on sandstone composition in an incised valley system: the Eocene La Meseta Formation, Seymour Island Antarctica. - Sedimentary Geology, 150: 301-321.

Martínez, I. (1992): Order Sphenisciformes. - In: Del Hoyo, J., Elliott, A. \& Sargatal, J. (Eds.): Handbook of the birds of the world, Vol 1, Ostrich to Ducks: 140-160; Barcelona (Links Editions).

Montes, M., Nozal, F., Santillana, S., Marenssi, S. \& Olivero, E. (2013): Mapa geológico de Isla Marambio (Seymour). Antártida; escala 1:20.000. $1^{\text {a }}$ edición. Serie Cartográfica.

Myrcha, A., Jadwiszczak, P., Tambussi, C., Noriega, G.F., Gazdzicki, A., Tatur, A. \& Del Valle, R. (2002): Taxonomic revision of Eocene Antarctic penguins based on tarsometatarsal morphology. - Polish Polar Research, 23: 5-46.

PoRęBSKI, S.J. (1995): Facies architecture in a tectonically 
controlled incised-valley estuary: La Meseta Formation (Eocene) of Seymour Island, Antarctic Peninsula. - Studia Geologica Polonica, 107: 7-97.

PourLis, A.F. (2011): Developmental malformations in avian species. Manifestations of unknown or genetic etiology - a review. - Asian Journal of Animal and Veterinary Advances, 6: 401-415.

Raidal, S.R., Shearer, P.L., Cannell, B.L. \& Norman, R.J.B. (2006): Micromelia in little penguins (Eudyptula minor). - Journal of Avian Medicine and Surgery, 20: 258-262.

Schmidt, R.E., Reavill, D.R. \& Phalen, D.N. (2003): Pathology of pet and aviary birds (No. SF994. S36 2003). Ames (Iowa State Press).

Tambussi, C., Acosta Hospitaleche, C., Reguero, M. \& Marenssi, S. (2006): Late Eocene penguins from West Antarctica: systematics and biostratigraphy. - In: FrANcis, J.E., Pirrie, D. \& Crame, J.A. (Eds.): CretaceousTertiary High-Latitude Palaeoenvironments, James Ross Basin, Antarctica. - Journal of the Geological Society of London, Special Publications, 258: 145-161.

Tumarkin-Deratzian, A.R., Vann, D.R. \& Dodson, P. (2006): Bone surface texture as an ontogenetic indicator in long bones of the Canada goose Branta canadensis (Anseriformes: Anatidae). - Zoological Journal of the Linnean Society, 148: 133-168.

Watanabe, J. (2016): Postnatal skeletal development and bone surface texture in limb bones of modern aquatic birds. - 9th International Meeting of the Society of Avian Paleontology and Evolution, Diamante (Argentina), 1-5 August 2016: 30.

Woodburne, M.O. \& Zinsmeister, W.J. (1984): The first land mammal from Antarctica and its biogeographic implications. - Journal of Paleontology, 58: 913-948.
Manuscript received: November 18th, 2016.

Revised version accepted by the Stuttgart editor: December 9th, 2016.

\section{Addresses of the authors:}

Carolina Acosta Hospitaleche, CONICET, División Paleontología de Vertebrados, Museo de La Plata, Paseo del Bosque s/n B1900FWA, La Plata. Facultad de Ciencias Naturales y Museo. UNLP. La Plata, Argentina;

e-mail: acostacaro@fcnym.unlp.edu.ar

Marcelo Reguero, CONICET. División Paleontología de Vertebrados, Museo de La Plata, Paseo del Bosque s/n B1900FWA, La Plata. Facultad de Ciencias Naturales y Museo. UNLP. La Plata, Argentina \& Instituto Antártico Argentino (Dirección Nacional del Antártico), 25 DE MAYO 1143, St. Martín, Buenos Aires, Argentina;

e-mail: mreguero@dna.gov.ar

Sergio Santillana, Instituto Antártico Argentino (Dirección Nacional del Antártico), 25 DE MAYO 1143, St. Martín, Buenos Aires, Argentina;

e-mail: ssantillana@dna.gov.ar 